\title{
Multi-Interactive Teaching Model of College English in Computer Information Technology Environment
}

\author{
https://doi.org/10.3991/ijet.v12.i12.7956 \\ Jianlan Wen $\left({ }^{\bowtie}\right)$ \\ Jilin Institute of Chemical Technology, Jilin, China \\ 714333259 @qq. com \\ Wei Wu \\ Sun Yat-sen University, Zhuhai, China
}

\begin{abstract}
The multi-interactive teaching mode of college English takes students as the center and the task as the link, realizing the combination of classroom teaching and network-based autonomous learning in information technology environment. This teaching model is characterized by integrated teaching methods, open teaching environment and hierarchical teaching management compared with the traditional classroom teaching methods. This paper took the interactive teaching model of college English based on computer information technology as the research object and the "construction", "interaction" and "cooperation" as the core guiding ideology based on the learning theory of constructivism and communicative theory, guiding the design of listening, speaking and reading experiments in college English teaching under the multi-interactive teaching model. This paper first described the application and concept of multivariate interactive teaching mode, and then introduced the related learning theories. By selecting non-English major college students of 2015 from Hunan Normal University as the application object of multi-interactive teaching model, this paper validated the effectiveness of multi-interactive teaching model for college English teaching through detailed teaching experimental design and comparative analysis of teaching achievements. Under the background of the rapid development of information technology, the new multiinteractive teaching mode opens up the multi-dimensional and multi-form language learning process, which is of innovative and practical significance for the teaching of college English.
\end{abstract}

Keywords-computer information technology, college English, multiinteraction, teaching experiment

\section{Introduction}

The process of international integration and the rapid development of society have put forward higher requirements for English learners. People with high English proficiency are more competitive in the talent market in the 21 st century [1]. Guided by the country's strategy of rejuvenating the country through science and education, 
China's education sector places great emphasis on English learning and the class hour of college English education accounts for a significant proportion of basic education in universities [2]. However, the gap between college students' practical ability of using English and the needs of the society is increasing day by day. The overall English level of undergraduates is low, which reflects the shortcomings of low efficiency and low output in college English teaching.

Computer information technology brings opportunities and challenges to all walks of life and the application of computer technology in the field of education is known to all. The positive effect of computer-assisted instruction technique, multimediaassisted teaching technique and artificial intelligence-assisted teaching technique on English teaching has also been verified by relevant scholars [3], but the number of researches on the reform of college English teaching from the perspective of teaching model is still less. However, under the computer information technology, the reform of the traditional English teaching mode is also an inevitable trend. The innovation of the teaching mode is the only way to reform the college English [4].

This article aims to establish a student-centered, task-based, teacher-directed college English teaching model and demonstrate its application effect in practical English teaching through experiments [5]. First of all, this paper introduces the concept and application of multi-interactive teaching mode of college English, expounds the constructivist learning theory and communicative learning theory that support the multi-interactive teaching mode and takes non-English major college students of 2015 from Hunan Normal University as the experiment object. Through detailed experimental content design and experimental results analysis and pre-test and post-test methods, this paper compares and analyzes the application effect of the multiinteractive teaching model among college students and summarizes the parts to be improved under the multi-interactive mode of college English, which is great important guiding significance for the reform of college English teaching mode and the improvement of college English teaching level.

\section{Multi-interactive teaching model of college English}

Interaction is the norm of teaching and the theme of education. Under the environment of information technology, people have higher requirements for the interaction between teachers and students, students and students, and students and machines. By unlocking the temporal and spatial constraints of interactive teaching, it is possible to achieve more efficient interaction under the new teaching model [6].

\subsection{Connotation of multi-interactive teaching model}

The elements in "multi-interaction" refer to various teaching factors that are related to learning and can interact with each other. These elements include: teachers, students, teaching materials, teaching environment, teaching conditions and teaching hardware. "Interaction" is to make full use of the interaction and interrelationship between various elements, promoting students to actively engaged in learning and 
realizing an organic integrity of multi-directional interaction between teaching, learning and various elements [7]. Multi-interactive teaching mode means that teaching activities are a multiple learning process of communication and dynamic interaction under the environment of information technology. By optimizing the interaction mode, adjusting the connection and function of relevant teaching elements and promoting the enthusiasm of students, a new comprehensive, multi-layer and harmoniously interacted teaching structure will be established.

\subsection{Conceptual model of multi-interactive teaching model}

Existing knowledge and learning experience play a crucial role in the new learning process. Some foreign students think that knowledge and skills in the future are a result of knowledge in the present abilities, motivation/affect and opportunity, as is shown in Formula 1.

$$
\mathrm{K}_{\mathrm{f}}=\mathrm{K}_{\mathrm{p}}+\mathrm{A}+\mathrm{M}+\mathrm{O}
$$

Based on the four basic elements of teacher, student, content and teaching process, this paper designs a conceptual model of multi-interactive teaching mode of college English driven by the task in order to improve the knowledge building ability and language learning ability of students [8]. The structure of the conceptual model is shown in Figure 1:

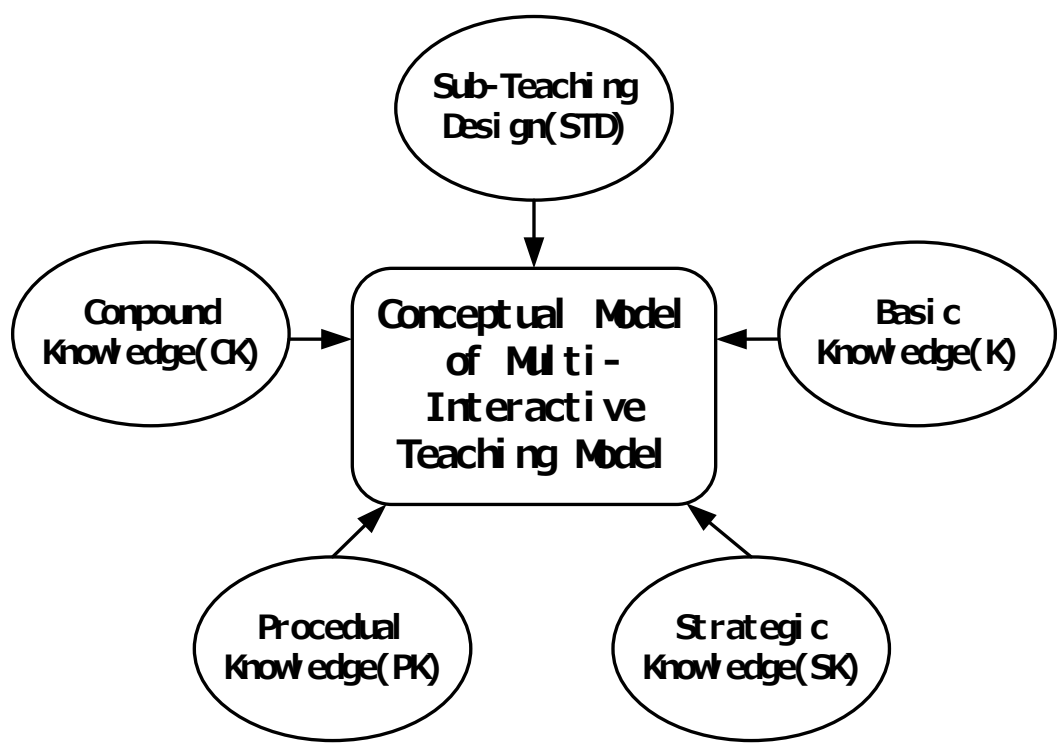

Fig. 1. The structure diagram of Conceptual model

The conceptual model shown in Figure 1 includes unit teaching design, basic knowledge, compound knowledge, strategic knowledge and procedural knowledge. 
Meanwhile, the conceptual model of multi-interactive teaching model in college English can be defined by a four-element formula, as is shown in Formula 2:

$$
\mathrm{CM}=(\mathrm{KM}, \mathrm{KMS}, \mathrm{TM}, \mathrm{TMS})
$$

$\mathrm{KM}=\{\mathrm{K}, \mathrm{CK}, \mathrm{SK}, \mathrm{PK}\}, \mathrm{KMS}==(\mathrm{KR} \mid \mathrm{KR}$ construction relationship of knowledge model), TM $=\{$ STD $\mid$ STDdesign pattern of unit teaching $\} ;$ TMS $=\{$ STDR $\mid$ STDRconstruction relationship of unit teaching design pattern $\}$. KM represents the basic English knowledge that students need to master, and requires students to reorganize their knowledge to realize interaction under certain circumstances TM (Teaching model), TMS (Teaching model system) corresponds to the teaching process design and teacher-oriented teaching content design layer. The traditional teaching mode requires teachers to teach students about the established teaching content according to established teaching schedule. However, in the multi-interactive teaching under the information environment, the teaching content needs to be restructured and teachers are required to teach students in accordance of their aptitude so as to realize the interaction among various teaching elements [9].

\subsection{Operation program model of multi-interactive teaching model}

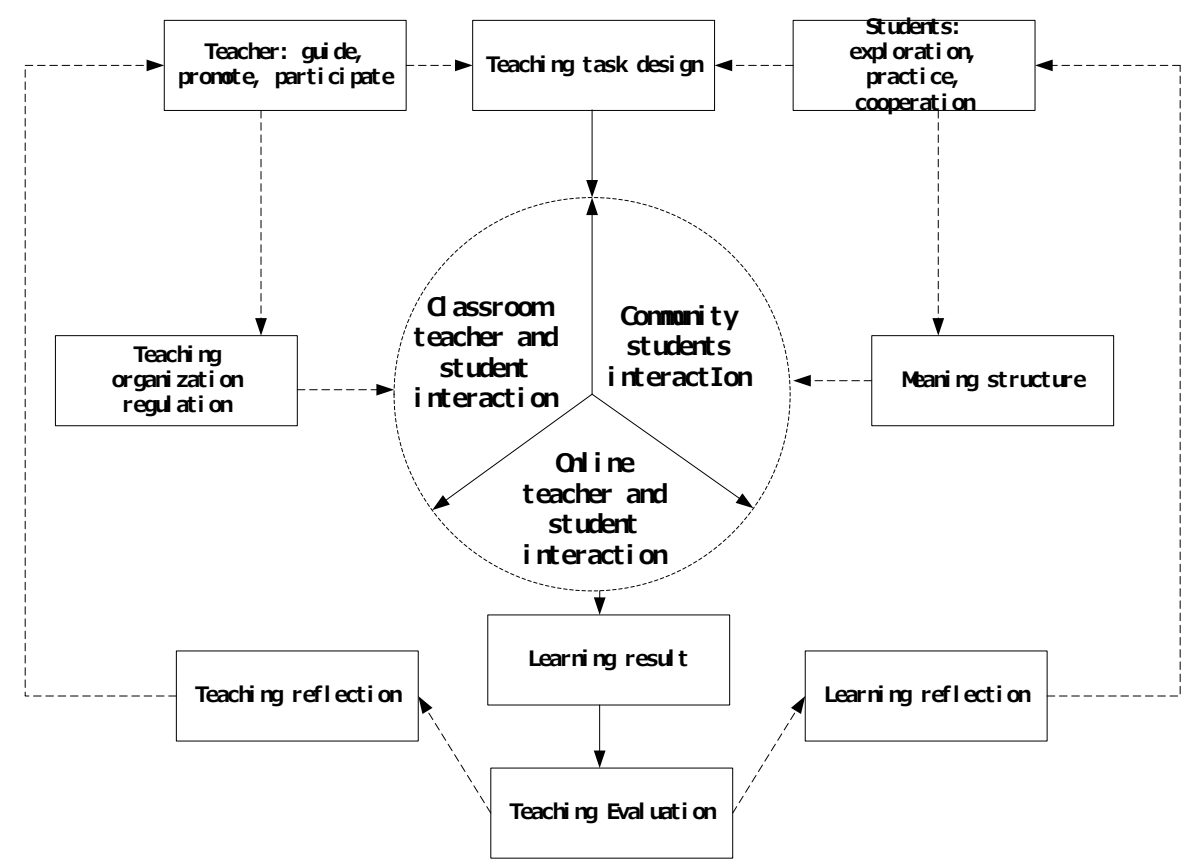

Fig. 2. Operation program of multi - interactive teaching mode

In teaching practice, the multi-interactive teaching mode of college English has four steps, which include: task design, environment creation, multiple interaction and 
evaluation feedback, and the teaching steps are flexible in the multi-interactive teaching mode. The program graph under multi-interactive teaching mode is shown in Figure 2.

The solid line indicates the body part of the teaching mode: (1) According to the teaching objectives, teachers design the teaching tasks to promote, coordinate and participate in student knowledge construction; (2) Students are engaged in interactive activities in class, after class and in cyber space and teachers are responsible for the adjustment of the design; (3) Students obtain learning outcomes through personal and team efforts around the teaching design, teaching requirements, teaching tasks; (4) Teachers and students make timely feedback on the completion of the learning outcomes and tasks.

\section{Explanation of relevant learning theories}

\subsection{Constructivism learning theory}

Constructivism is rooted in rationalism and empiricism. The constructivism learning theory think that students are the active constructors of learning rather than passive recipients. Students are required to become the main body of information processing rather than the passive indoctrinators of knowledge. Teachers need to transform from teaching knowledge to counseling students, becoming the helpers and instructors of constructivism learning [10].

The teaching design of constructivism learning theory includes two major parts: the first part is the design of the learning environment and the other part is the design of self-learning strategy. In the process of learning, the scope of students' learning resources has gone far beyond the textbooks. In the learning process of constructivism, the relationship among teachers, students, teaching media and teaching contents has changed from one-way to multi-directional, interaction, interdependence, interconversion, teacher-student interaction, student-student interaction, and humancomputer interaction [11].

\subsection{Communication theory}

Communicative theory is based on the communicative approaches, and the communicative approaches believe that language learning is the process of language communication, emphasizing the interdependent relationship between language and communication. Two-way communication is more conducive to language acquisition than one-way communication. The communicative competence of individuals can be summarized into four aspects: 1. grammaticality; 2. feasibility or acceptability of language; 3. deliberation of language; 4. frequency of language appearance [12]. Communication theory tells us that language learning is not only the cultivation of language skills, but the cultivation of communicative competence using the language.

In language teaching practice, the foreign language teaching is unique under the guidance of different learning theories. The content of foreign language teaching 
needs to be designed and implemented flexibly according to different actual situations. Through teaching design phases, the optimal teaching effect of different types of courses and different teaching contents can be achieved. Under information technology environment, multi-interactive teaching mode of college English needs to take students as the center and tasks as the link, and try to realize the organic combination of classroom teaching and network-based autonomous learning [13].

\section{Experiment design and analysis of multi-interactive teaching model}

At present, the computer hardware facilities in institutions of higher learning in China have basically achieved, including digital language laboratory and network multimedia laboratory. The completeness of hardware facilities provides hardware technical support for the multi-interactive teaching model of college English. In order to verify whether the multi-interactive teaching mode of college English can facilitate the comprehensive ability of listening, speaking and reading and investigate students' evaluation of the new teaching model, this paper analyzes students' learning strategies, autonomous learning ability and academic performance under the multiinteractive teaching mode through the experimental design to evaluate its impact on the English listening, speaking and reading ability of students; Through the questionnaire, we analyzed the students' evaluation of the multi-interactive teaching mode [14].

\subsection{Experimental subjects}

The subjects were non-English major college students of 2015 from Hunan Normal University and the total number of students is 74 . The pre-experiment learning background and English learning performance are shown in Table 1.

Table 1. The pre-experiment learning background and English learning performance

\begin{tabular}{lcc}
\hline \multicolumn{1}{c}{ Type } & Test group & Control group \\
\hline Number of student & 38 & 36 \\
Number of girls & 20 & 19 \\
Admission average score & 78.21 & 79.29 \\
Weekly extracurricular listening time & 1.2 & 1.4 \\
Weekly extracurricular reading time & 1.1 & 1.2 \\
\hline
\end{tabular}

It can be seen from the table that the learning performance and extracurricular English learning time of the experimental group and control group are basically the same before the experiment.

\subsection{Experimental scheme}

The learning materials of the experimental group and the control group of are "College English Listening and Speaking Course" and "Experiencing college English 
learning system". This system is installed on the campus network server, and students can $\log$ in at any time to learn. The learning tasks of the experimental group are the tasks in "teacher-student, student-student and student-computer" interactive teaching and autonomous learning plans. After the experiment, the change of learning strategies and autonomous learning ability and the change of listening and reading performance are compared. Through the evolution of supervisors, the experimental results are comprehensively analyzed. The teaching experience, teaching ability and professional level of teachers in the experimental group and the control group are the same [15].

\subsection{Experiment tools}

The experiment tools used in the listening and speaking experiment include questionnaires, audio-visual testing, subjective evaluation of students. Two set of questions are included in the audio-visual ability test, which are pre-test questions. The first part of listening in each set is a short dialogue, containing 10 questions; the second part is a long dialogue and essay; the third part is a compound blank filling question.

The experimental tools used in reading experiments include the reading strategy questionnaire, reading comprehension test of CET-4, and record of students' learning history. The test scores of pre-test and post-test of reading comprehension are 40 points. The pre-test test is arranged in the first week of teaching, while the post-test is arranged in the final exam. The difficulty of pre-test and post-test strives to be similar.

\subsection{Experimental process}

Listening and speaking experiment. Pre-test test is arranged in the first week of teaching, at the same time the investigation and analysis of oral learning strategies and oral learning requirements are conducted in the experimental group and the control group. For the experimental group, the multi-interactive teaching mode and implementation plan are introduced, emphasizing the importance of cooperative learning and autonomous study. The listening and speaking interaction model of college English based on autonomous study and cooperative learning is shown in Figure 3.

Through the interaction between teachers and students, students and students, and students and computers, students in the experimental group are guided by their teachers to adjust learning attitude, exchange learning experience and stimulate learning interests. This interactive mode enhances the autonomous learning program planning and strengthens self-management and self-restraint, achieving the multi-interactive teaching.

Reading experiment. The pre-test and reading strategy questionnaire is conducted in the first week, and the communication with the students in the experimental class is carried out in the second week, which pays attention to the classroom text analysis, online article expansion analysis in order to accelerate the cultivation of language awareness. Students participate in the final in the 18th week, and then the post-test data is collected. Teachers design and assign guiding learning tasks, guide students to complete the reading tasks within the required time, master the psychological change 


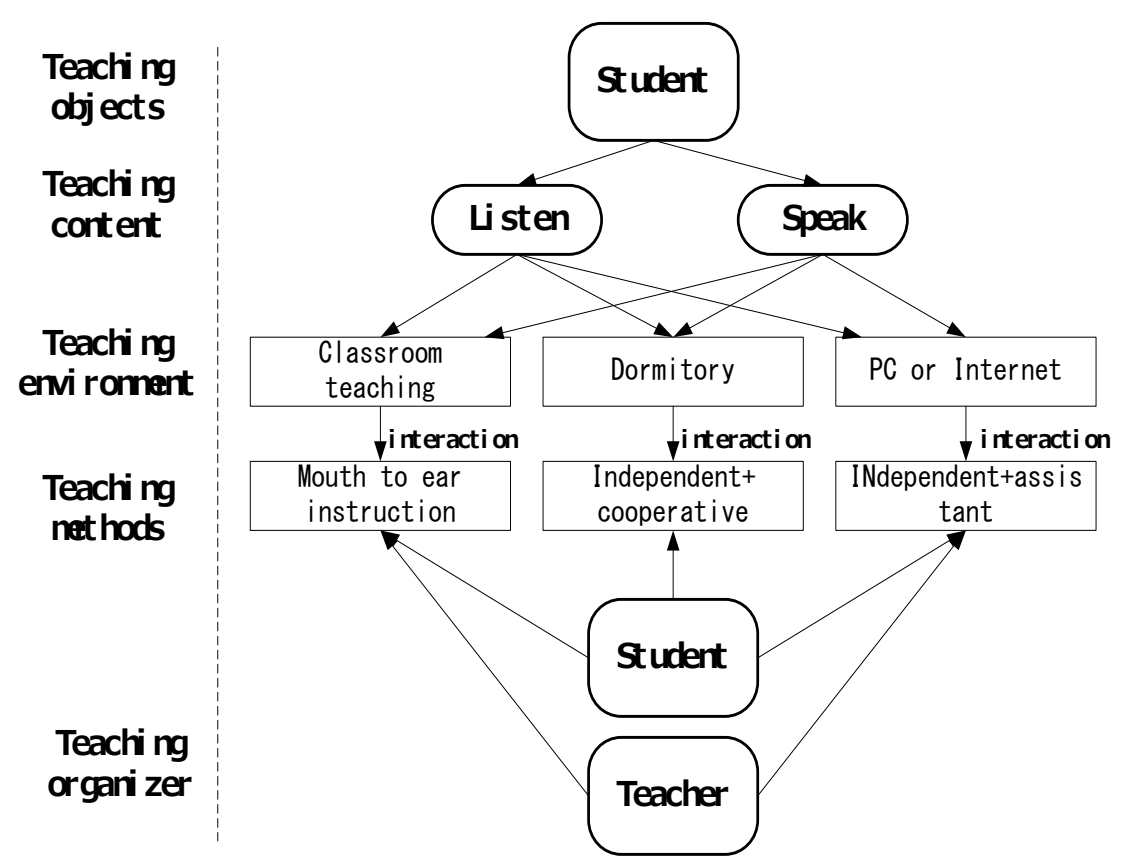

Fig. 3. The college English listening and speaking interaction mode

of students in the learning process and evaluate the common problems of reading appear in class. Students can learn from each other and comment on each other inside and outside the classroom and they can record their own reading performance using the computer network. Students can also search related reading materials based on their interests. Through the above multi-interactive model, students' interest in reading is stimulated, and they can use free discussion to understand and exchange the learning. The language application ability and problem-solving ability are thus cultivated.

\subsection{Analysis of experimental results}

Experimental result of listening and speaking. As shown in Table 2, the average listening scores of the pre-test of the control group and the experimental group before the test were 16.30, 25.03 and 14.74, 25.72 respectively. After $\mathrm{P}$ value test, the $\mathrm{P}$ values were 0.065 and 0.054 respectively, which were greater than 0.05 , indicating no significant difference in the pre-test scores. After 12 weeks of experiment, the experimental group received multi-interactive teaching model while the control group accepted the traditional teaching mod. The average results of listening and speaking were $21.22,26.43$ and 18.90,27.03 respectively and after $\mathrm{P}$ value test, the $\mathrm{P}$ values were 0.008 and 0.031 respectively, which were less than 0.05 , indicating significant differences between the two groups. The performance of listening and speaking was more remarkable. 
Paper-Multi-Interactive Teaching Model of College English in Computer Information Technology En...

Table 2. The listening and oral performance statistics of control group and test group

\begin{tabular}{|c|c|c|c|c|c|c|c|}
\hline \multicolumn{2}{|c|}{ Test results } & Type & mean value & variance & $\begin{array}{l}\text { degree of } \\
\text { freedom }\end{array}$ & t value & probability \\
\hline \multirow{4}{*}{ Pretesting } & \multirow{2}{*}{ Listening } & Control group & 16.30 & 3.45 & \multirow{2}{*}{74} & \multirow{2}{*}{1.873} & \multirow{2}{*}{0.065} \\
\hline & & Test group & 14.74 & 3.76 & & & \\
\hline & \multirow{2}{*}{ Oral } & Control group & 25.03 & 1.64 & \multirow{2}{*}{74} & \multirow{2}{*}{-1.958} & \multirow{2}{*}{0.054} \\
\hline & & Test group & 25.72 & 1.43 & & & \\
\hline \multirow{4}{*}{ Aftertest } & \multirow{2}{*}{ Listening } & Control group & 21.22 & 3.38 & \multirow{2}{*}{74} & \multirow{2}{*}{2.724} & \multirow{2}{*}{0.008} \\
\hline & & Test group & 18.90 & 3.99 & & & \\
\hline & \multirow{2}{*}{ Oral } & Control group & 26.43 & 1.17 & \multirow{2}{*}{74} & \multirow{2}{*}{-2.201} & \multirow{2}{*}{0.031} \\
\hline & & Test group & 27.03 & 1.18 & & & \\
\hline
\end{tabular}

Experimental result of reading. It can be seen from Table 3 that reading comprehension scores of the experimental group was much more impressive than that of the control group and there was significant difference between the reading comprehension scores in pre-test and post-test. post-test scores of the experimental group improved to 29.5 points.

Table 3. The reading performance statistics of control group and test group

\begin{tabular}{|c|c|c|c|c|c|c|}
\hline Group type & Test Type & mean value & variance & degree of freedom & t value & probability \\
\hline \multirow{2}{*}{ Control group } & Pretesting & 24.6 & 5.48 & \multirow[t]{2}{*}{ - } & \multirow{2}{*}{3.250} & \multirow{2}{*}{0.002} \\
\hline & Aftertest & 27.4 & 5.35 & & & \\
\hline \multirow{2}{*}{ Test group } & Pretesting & 25.6 & 4.6 & \multirow{2}{*}{74} & \multirow{2}{*}{4.052} & \multirow{2}{*}{0.000} \\
\hline & Aftertest & 29.5 & 4.89 & & & \\
\hline
\end{tabular}

Investigation and analysis of students' attitude toward multi-interactive teaching model. The main questions of the questionnaire include: 1. Are you happy with the new teaching model? 2. Are you satisfied with the arrangement of the teaching process? 3. If you have the opportunity, would you like to participate in multi-interactive teaching model? 4. Are you willing to recommend multi-interactive teaching model to other students? A total of 74 questionnaires were sent and 74 valid questionnaires were collected. The statistical results are shown in Table 4.

Table 4. Questionnaire

\begin{tabular}{|l|c|c|c|c|c|}
\hline \multicolumn{1}{|c|}{ Questions } & totally consent & agree & general & disagree & strongly disagree \\
\hline $\begin{array}{l}\text { If the new teaching } \\
\text { mode makes you } \\
\text { happy }\end{array}$ & $37.5 \%$ & $25 \%$ & $12.5 \%$ & $20 \%$ & $5 \%$ \\
\hline $\begin{array}{l}\text { If you are satisfy } \\
\text { with the teaching } \\
\text { process }\end{array}$ & $35 \%$ & $22.5 \%$ & $17.5 \%$ & $20 \%$ & $5 \%$ \\
\hline $\begin{array}{l}\text { If you want to } \\
\text { participate in new } \\
\text { teaching mode }\end{array}$ & $47.3 \%$ & $26.3 \%$ & $13.1 \%$ & $13.1 \%$ & 0 \\
\hline $\begin{array}{l}\text { Will you recom- } \\
\text { mend new teaching } \\
\text { mode to your friend }\end{array}$ & $50 \%$ & $25 \%$ & $12.5 \%$ & $12.5 \%$ & 0 \\
\hline
\end{tabular}


It can be seen from Table 4 that the multi-interactive English teaching model in the computer information environment can be accepted by more than $62.5 \%$ of students. The improvement of comprehensive English proficiency brought by teaching mode of teacher-student interaction, student-student interaction, and human-computer interaction has been recognized by students. More than $70 \%$ of the students in the control group are willing to participate in the multi-interactive teaching model and are willing to recommend this new model to other students.

\subsection{Teaching implications}

\section{Teaching implication of listening and speaking experiment.}

1. The effectiveness of speaking strategy training. Students are required to develop the habit of oral communication in the learning process and arrange more time for oral communication activities.

2. The dual nature of human-computer interaction. Human-computer interaction provides students with a more convenient learning environment and method, but the mechanical nature of human-computer interaction requires the supplement of teacher-student interaction and student-student interaction.

3. Irreplaceable role of teacher. The role of teachers under the new mode is very important. The characteristics of student-centered do not pay down the importance of teachers. Teachers should provide students with high-quality language resources and language learning samples.

Teaching implication of reading experiment. Rich reading input is the guarantee of the improvement of reading ability. In terms of teachers, they should broaden the knowledge base of reading materials; in terms of students, they should search new reading materials autonomously. Through the autonomous learning with guidance from teachers, students will pay attention to the learning process and develop the habit of planning and managing study. In addition, the active participation of students is a necessary condition for improving reading comprehension ability. The key for students to improve reading comprehension ability is to seek resources, find out the problems, exchange views and solve problems in the environment of computer information technology.

\section{Conclusion}

The traditional English teaching model is a major obstacle to the teaching level and student performance of college English. This article studied the method of improving college English education from the teaching model reform and put forward the interactive teaching model of college English in the computer environment. Based on the explanation and elaboration of relevant theoretical knowledge, this paper designed the teaching experiment and verified the positive effect of the new teaching mode on English listening, speaking and reading ability. The main conclusion and research significance of this paper are as follows: 
1. This paper proposed a multi-interactive teaching mode with "teacher-student, student-student and student-computer" as the core.

2. The research in this paper has opened up a new path for reforming college English teaching from the teaching model, which is guiding significance for the reform of college English.

\section{$1 \quad$ References}

[1] Grabowski, M. (2014). The role of transnational integration in forming of northeast Asian community. Tectonics, 20(6): 959-975. https://doi.org/10.15611/pn.2014.370.03

[2] Lang, W. (2011). The role of academic pharmacy to influence safety through science and education. American Journal of Pharmaceutical Education, 75(4): 78. https://doi.org/10.5688/ajpe75478

[3] Liu. (2013). The application of computer technology in music education. International Journal of Technology Management, 88-90.

[4] Diaz, L.C., Algorry, A., Eschoyez, M., Barto, C. (2013). Actions towards the application of intelligent systems in computer education. IEEE Latin America Transactions, 11(1): 591-595. https://doi.org/10.1109/TLA.2013.6502866

[5] Richardson, D.C., Richardson, J.S. (1994). Kinemages--simple macromolecular graphics for interactive teaching and publication. Trends in Biochemical Sciences, 19(3): 135. https://doi.org/10.1016/0968-0004(94)90207-0

[6] Hacker, C., Sitte, R. (2004). Interactive teaching of elementary digital logic design with winlogilab. IEEE Transactions on Education, 47(2): 196-203. https://doi.org/10.1109/TE.2 004.824843

[7] Peng, X.I. (2012). Application of interactive and opening teaching mode in polymer chemistry teaching. Polymer Bulletin.

[8] Chen, D., Li, Z., Wang, T. (2014). Exploration and practice: a competition based project practice teaching mode. Mechatronics, 24(2): 128-138. https://doi.org/10.1016/j.mechatron ics.2013.12.009

[9] Brown, K. (2015). Theorizing learning process: an experiential, constructivist approach to young people's learning about global poverty and development. Tobacco Control, 7(1): 217-223. https://doi.org/10.18546/IJDEGL.07.1.04

[10] Coupal, L.V. (2004). Constructivist learning theory and human capital theory: Shifting political and educational frameworks for teachers' ict professional development. British Journal of Educational Technology, 35(5): 587-596. https://doi.org/10.1111/j.00071013.2004.00415.x

[11] Zhao, Y., Zhang, M., Wang, S., Chen, Y. (2005). Exploring constructivist learning theory and course visualization on computer graphics. Lecture Notes in Computer Science, 3483, 1-9. https://doi.org/10.1007/11424925 1

[12] Corso, J.P.D., Kephaliacos, C., Plumecocq, G. (2015). Legitimizing farmers' new knowledge, learning and practices through communicative action: application of an agroenvironmental policy. Ecological Economics, 117(12): 86-96. https://doi.org/10.1016/j.eco lecon.2015.05.017

[13] Suárez-Warden, F., Barrera, S., Neira, L. (2015). Communicative learning for activity with students aided by augmented reality within a real time group HCI. Procedia Computer Science, 75: 226-232. https://doi.org/10.1016/j.procs.2015.12.242

[14] Walatara, D. (1973). An experiment with the bilingual method for teaching English as a complementary language. Lancet, 212(2441): 77. 
Paper-Multi-Interactive Teaching Model of College English in Computer Information Technology En..

[15] McAdow. (2010). An experiment in teaching English grammar incidental to composition. Journal of Hazardous Materials, 183(1-3): 182-188.

\section{Authors}

Jianlan Wen is with the School of Foreign Languages, Jilin Institute of Chemical Technology, Jilin 132022, China.

Wei Wu is with the School of International Studies, Sun Yat-sen University, Zhuhai 519000, China.

Article submitted 09 November 2017. Published as resubmitted by the authors 09 December 2017. 